\title{
The impact of acquiring EU status on the earnings of East European migrants in the UK: Evidence from a quasi-natural experiment
}

\author{
$26^{\text {th }}$ October 2016 \\ Forthcoming*, British Journal of Industrial Relations \\ Martin Ruhs \\ University of Oxford \\ martin.ruhs@conted.ox.ac.uk
}

\begin{abstract}
:
On $1{ }^{\text {st }}$ May 2004, ten new states - including the "A8" countries in Central and Eastern Europe - joined the European Union (EU). This paper explores the impact of EU enlargement on A8 workers who were already working in the UK before $1^{\text {st }}$ May $2004-$ legally or illegally. More specifically, the paper analyses the impact of the change in the legal (immigration) status that A8 workers experienced on $1^{\text {st }}$ May 2004 on their earnings in the UK. The empirical analysis employs difference-in-difference estimation using data obtained from a relatively small but unique survey of migrant workers from four of the A8 countries (Poland, Czech Republic, Slovakia, and Lithuania) and two other East European countries (the Ukraine and Bulgaria), carried out one month before and 6-8 months after EU enlargement in May 2004. The results of this exploratory analysis suggest a statistically significant and positive impact of acquiring EU status on earnings. The data further indicate that, in part, this effect was brought about by A8 workers gaining the right to freely change jobs after EU enlargement. There is no evidence of a 'legalization effect' on earnings.
\end{abstract}

\section{Acknowledgements:}

For their helpful comments on earlier drafts of this paper, I am grateful to Mary Gregory, Lindsay Lowell, Carlos Vargas-Silva, and three anonymous referees.

This paper draws on data collected in a major research project, Changing status, Changing lives? The socio-economic impact of EU Enlargement on low-wage migrant workers in the $U K$. The four principal investigators in Changing Status, Changing Lives? were Bridget Anderson, Ben Rogaly, Martin Ruhs and Sarah Spencer. The project was funded by the Joseph Rowntree Foundation (JRF) and the Economic and Social Research Council (ESRC). I thank Bridget Anderson, Ben Rogaly and Sarah Spencer for their permission to use the data for this paper.

\section{*Note:}

This version is "post-refereeing" but "pre-copyediting". 


\section{Introduction}

On $1^{\text {st }}$ May 2004, ten countries joined the European Union (EU) including the "A8" countries in Central and Eastern Europe - the Czech Republic, Estonia, Hungary, Latvia, Lithuania, Poland, Slovakia and Slovenia - plus Cyprus and Malta. Along with Ireland and Sweden, Britain was in a minority among the member states of the pre-enlarged EU (EU15) to grant A8 nationals free access to the labour market immediately upon EU enlargement. A8 workers have subsequently been free to migrate and take up employment in the UK without restrictions (as long as they registered in the "Worker Registration Scheme"). EU enlargement also meant that overnight A8 nationals who were already working in the UK before 1st May 2004 experienced a change of legal (immigration) status, acquiring most of the rights of an EU national. This includes the right to live and work in the UK without restrictions, to remain permanently in the UK, and to be joined by dependants. For A8 nationals residing in the UK illegally, 1st May 2004 was, in effect, an amnesty. For those in the UK legally but with restrictions on the work that they were permitted to do, acquiring EU rights has given them the freedom to change their employer and sector of employment.

The increase in the migration of A8 workers to the UK since May 2004 has been significant and much larger than anticipated by the Government. The number of A8 nationals in employment in the UK increased from fewer than 100,000 in early 2004 to over 500,000 in early 2008 and, after remaining relatively stable for most of the sharp economic downturn during 2008 and 2009, continued to rise to just under one million in 2015 (Office for National Statistics 2015). This triggered a heated public debate - and keen interest in new research - about the economic and social impacts of immigration from Eastern Europe.

Most of the economic research on A8 migrants in the UK has focused on the labour market performance of "newcomers", i.e. of arrivals after May 2004 (see, for example, Clark and Drinkwater 2008; Blanchflower and Shadforth 2009) and/or the effects of A8 migrants on other workers in the UK labour market (Gilpin et al. 2006; Lemos and Portes 2008; Lemos 2010; Migration Advisory Committee 2012; Devlin et al. 2014). In contrast, this paper explores the impact of EU enlargement on A8 workers who were already working in the UK before $1^{\text {st }}$ May 2004 - legally or illegally. More specifically, the paper analyses the impact of the change in the legal (immigration) status that A8 workers 
experienced on $1^{\text {st }}$ May 2004 (e.g. from work permit holder to EU national; or from "illegally resident" to EU national, etc.) on their earnings in the UK. To address this issue, I consider EU enlargement as a quasi "natural experiment" which changed the legal (immigration) status of A8 migrants but did not affect the status of other East European migrants in the UK. In the absence of large-scale data, the paper conducts empirical analysis based on a relatively small but unique survey of migrant workers from four of the A8 countries (Poland, Czech Republic, Slovakia, and Lithuania) and two other East European countries (Ukraine and Bulgaria), carried out one month before and 6-8 months after EU enlargement in May 2004. The analysis employs difference-in-difference estimators to assess whether and how the change in A8 migrants' legal status affected their earnings.

The analysis is 'exploratory', in the sense that it is based on relatively small-scale data, but it sheds light on a key issue that analyses based on the currently available large scale survey data cannot address - namely the effects of an important regulatory change on earnings. The paper contributes to the research literature on East European migrants in the UK's labour market, and to wider research on the role of immigration status as a determinant of migrants' outcomes in the labour market.

The paper begins, in section 2, with a brief discussion of the UK Government's labour immigration policies in the 2-3 years prior to EU enlargement in May 2004 and a review of the existing literature on the relationship between immigration status and migrants' outcomes in the labour market. This is followed, in section 3, by a discussion of the sources and descriptive statistics of the data used in the empirical analysis. Section 4 explains the estimation methods and discusses the results including their limitations.

The main conclusion of the analysis in this paper is that acquiring EU status had a statistically significant and positive impact on the relative earnings of A8 migrants who had already been working in the UK before $1^{\text {st }}$ May 2004. The analysis suggests that this positive effect on earnings was, at least in part, brought about by A8 workers gaining the right to freely change employers and jobs after EU enlargement. Acquiring the legal right to free choice of employment in the UK raised the earnings of A8 workers directly by enabling them to change into higher paying jobs, and, I argue, also indirectly by increasing their bargaining power vis-à-vis their existing employers in their current jobs. The paper 
does not find evidence that the increase in earnings was significantly influenced by the "legalization effect" of EU enlargement for all those A8 migrants who had been working illegally in the UK before $1^{\text {st }}$ May 2004. This third result is more tentative given the difficulties with establishing the legal status of migrant workers who participated in this study, especially before EU enlargement.

This is the first systematic analysis of the effects of acquiring EU status on the earnings of East European migrants in the UK and the EU15 countries more generally. Although based on data collected over ten years ago, the analysis continues to be highly relevant not only to current academic research but also to ongoing European debates about the labour market effects of past and future EU enlargements as well as global policy debates about the pros and cons of different types of legalization programmes and temporary migration policies.

\section{Background}

\section{1 “Managed Migration” prior to EU enlargement in May 2004}

Before EU enlargement in 2004, the UK's "Managed Migration” policies for employing migrants in low-skilled occupations were relatively small in scale, sectorspecific, and much more restrictive in terms of rights after admission than policies toward skilled migrants. For example, the sector specific schemes for employing migrants in lowskilled jobs in agriculture and hospitality issued strictly temporary work permits that were valid for one year or less, with the overall numbers restricted by annual quotas of fewer than 25,000. Consequently, employers in search for workers for low skilled jobs often turned to non-EEA students - one of the largest immigration categories since the early 2000s - who could be legally employed for 20 hours per week during term time and fulltime during vacations.

A significant number of employers also filled their low-skilled vacancies by hiring migrants who were residing and/or working illegally in the UK. The Home Office estimated that the number of migrants illegally resident ("i.e. without leave to remain") in 2001 ranged from 310,000 to 570,000 , with a median estimate of 430,000 which is 
equivalent to about 0.7 percent of the UK population (Woodbridge 2005) ${ }^{1}$. Most illegally resident migrants were thought to be working in low-wage jobs in agriculture and food processing, construction, the care sector, cleaning and in hospitality (IPPR 2006). Although Section 8 of the Asylum and Immigration Act 1996 makes it a criminal offence to employ an individual over the age of 16 who does not have the entitlement to be in the UK, enforcement against employers who employ migrants illegally was very low. Between 1998-2003, only 9 employers were successfully prosecuted for illegally employing migrants under Section 8 (UK Home Office 2005).

EU enlargement in May 2004 provided the Government with an opportunity to address the apparent gap between employer demand for workers for low-skilled jobs, and the available channels for legal labour immigration at the time. The decision to grant A8 nationals free access to the UK's labour market was clearly part of the Government's strategy for migration management, expanding migration to fill vacancies in skilled and especially in low-waged occupations, where employers found it difficult to legally employ migrants.

In February 2004 a special and temporary "Workers Registration Scheme" (WRS) was put into place to monitor (but not restrict) the inflow of A8 workers taking up employment in the UK. Just under one million A8 nationals - of whom about two thirds were from Poland - applied for employment registration between May 2004 and March 2009 (UK Home Office 2009). While the vast majority were "newcomers" that migrated to the UK after EU enlargement, the registration figures also include A8 workers who had already been working in the UK before May 2004 including migrants who used the WRS to regularize their status. According to Gilpin et al. (2006), up to 30 percent - about 89,000 in absolute numbers - of A8 workers who registered between May 2004 and September 2005 were from applicants who had already been in the UK before $1^{\text {st }}$ May 2004.

At the same time as opening the labour market to A8 workers, the government also introduced measures to strengthen the enforcement of employer sanctions. On $1^{\text {st }}$ May 2004, the Government introduced the Immigration (Restrictions on Employment) Order 2004 which, among other things, revised the list of specified documents which may be taken to provide evidence of entitlement to work. Although enforcement efforts in relation

\footnotetext{
${ }^{1}$ A more recent study (Gordon et al. 2009) estimated 524,000-947,000 illegal residents in the UK in 2007.
} 
to illegal migrant working increased - according to the Home Office the number of "successful operations" increased from 390 in 2003 to 1,098 in 2004 - prosecution rates and fines imposed on employers following section 8 convictions remained very low in the two years following EU enlargement. In 2004-05, 21 employers were successfully prosecuted for illegally employing migrants under Section 8, compared to a total of 3 during 2001-03 (UK Home Office 2006). More than half of section 8 convictions in 200405 resulted in fines of less than $£ 700$, with four employers fined the maximum of $£ 5,000$ (UK Home Office 2005). Prosecutions and fines imposed on employers increased a little after 2008, partly due to the introduction of a civil penalty regime (see Aliverti 2013).

\subsection{Research on immigration status and earnings}

For the purpose of discussing potential impacts on migrants' outcomes in the labour market, it is useful to broadly distinguish between three types of immigration status: “illegally resident", "temporary (legal) resident", and "permanent (legal) resident". Migrants with the right to permanent residence in the UK - a group that includes all citizens of EU member states - enjoy the same employment rights as UK citizens. In contrast, migrants who are illegally resident or working on legal temporary permits face a number of restrictions in the UK's labour market. These restrictions may, in a variety of ways, impact on migrants' earnings.

\section{Theoretical considerations}

By definition, illegally resident migrants have no legal right to residence or work. They are subject to removal and their employers are subject to fines. Their "deportability" can put illegally resident migrants in a vulnerable position in the host country (De Genova 2002). Some employers may offer illegally resident migrants lower wages and inferior employment conditions, either because they take advantage of migrant's deportability and/or simply to account for the increased risk associated with employing migrants without legal residence rights. Taylor (1992) suggests that cost-minimising employers will allocate illegally resident migrants to jobs where the expected cost of apprehension is lowest; and that such jobs are likely to be relatively low skilled jobs. Employers may also take advantage of the potentially lower elasticity of labour supply of illegally resident migrants 
which would make them less likely than other workers to quit their jobs in response to a reduction in wages (Hotchkiss and Quispe-Agnoli 2013). If employers enjoy monopsonistic power in the labour market (see, for example, Manning 2011), migrants without legal status may receive lower wages. This type of employer discrimination is most likely to occur when employers know about the (illegal) immigration status of their migrant employees. It may, however, also arise from employers' perceptions - rather than direct knowledge - of their workers' immigration status. Qualitative research in the UK has shown that, in practice, employers frequently do not know or "choose not to know" their workers immigration status (Ruhs and Anderson 2008).

Deportability may also impact on migrants' earnings through mechanisms that are not directly related to employer discrimination. Importantly, there are various ways in which illegal residence status may alter migrants' behavior in the labour market (Kossoudji and Cobb-Clark 2002). Migrants without the right to reside may, for example, have lower reservation wages than workers with the right to legal residence. The fear of being deported could also discourage migrants from investing in the development of host-country specific human capital (Chiswick 1984). At the same time, the risk of deportation that illegally resident migrants face could increase their work effort compared to workers with legal status (Stark 2007). Illegal residence status could also impact on the kinds of social networks that migrants may access, which, in turn may affect migrants' access to wellpaying jobs (Massey 1987). A more general point is that illegal status usually constrains migrants' choice of employment in the host country and thereby prevents migrants from maximizing the returns to their human capital (Calavita 1992). For an example, illegally resident migrants may self select into temporary agency working because employment agencies are sometimes perceived to be less rigorous in their check of documents than businesses recruiting and employing migrants directly (Anderson et al. 2006). Since agency workers enjoy fewer employment rights than other temporary or permanent workers, they may be vulnerable to employment under low wages and sub-standard working conditions (see TUC 2007, 2006).

Although not at constant risk of removal, migrants employed on legal temporary work permits in low-skilled occupations may also experience lower earnings because of their immigration status. Temporary work permits, such as those issued under the UK's 
Sector-based Schemes (SBS) and Seasonal Agricultural Worker Scheme (SAWS), restrict migrants' employment to the sector and employer specified on the work permit. Where a change of employer is allowed, a new application for a work permit is usually required by the new employer. By restricting migrants' choice of employment in the labour market, this requirement naturally reduces workers' bargaining power and may make it difficult to leave jobs offering adverse employment conditions (Lowell and Avato 2007). Furthermore, a temporary migrant's right to legal residence is usually tied to ongoing employment in the UK. As it can be the case with illegally resident migrants, unscrupulous employers may take advantage of temporary migrants' employment restrictions and offer employment conditions that are lower than those enjoyed by migrants with permanent residence status. Whether and to what degree migrants employed on legal temporary permits have a stronger or weaker bargaining position vis-a-vis their employers is an empirical question. Apgar (2015) argues that illegally employed migrants may have some advantages over migrants who are legally employed on temporary work permits, e.g. in terms of their job mobility and opportunities for improvement in occupational standing.

\section{Empirical findings}

In the UK and elsewhere, empirical research on the relationship between immigration status and migrants' earnings has been hampered by a lack of data. Labour force surveys and other large scale surveys typically do not record respondents' immigration status. Migrants residing illegally are unlikely to participate in government surveys at all. Most of the existing studies of the determinants of migrants' earnings in the UK (see, for example, Lemos, S. 2013; Dickens and McKnight 2008; Drinkwater et al. 2006; Dustmann and Fabbri 2005; Shields and Wheatley Price 1998, Bell 1997) have thus been unable to take account of respondents' immigration status (especially of "illegal status"). A few studies used data from the UK's labour force survey to analyse the impact of "status on arrival" on migrants" earnings. For example, Clark and Lindley (2009) distinguish between migrants entering the UK for employment purposes, having completed their education ("labour market entrants"), and migrants who arrive to complete their education in the UK ("education entrants") and subsequently enter the labour market. The study finds that the evolution of earnings differ significantly between the two groups, with 
education entrants benefiting from exposure to the UK education system. In an earlier study, Lindley (2002) showed that there is a significant difference in economic performance between migrants who arrive in the UK as refugees and those who arrive as economic migrants. Refugees, especially those who are non-white, are found to suffer from significant earnings penalties.

Most of the empirical research relevant to this paper has been carried out in the US, especially in the aftermath of the 1986 Immigration Reform and Control Act (IRCA). IRCA gave amnesty (including eventual permanent residence status) to undocumented immigrants - about 1.7 million outside agriculture ${ }^{2}$ - who could prove continuous residence in the US since 1982. IRCA also included provisions for sanctions on employers who "knowingly" hired undocumented migrants; and for increased border control. To help assess the impact of IRCA, a random sample of legalized migrants was surveyed in 1989 and in a follow up survey in 1992. A number of studies used the data taken from these "Legalized Population Surveys" (LPS) to explore the impact of legal status on migrants' earnings. Rivera-Batiz (1999) found that illegal status adversely affects migrants' earnings even after controlling for migrants individual characteristics. This finding contradicted the results from earlier (pre-IRCA) studies which often concluded that the wage differential between legal and illegal immigrants could be mostly accounted for by differences between the characteristics and human capital of the two groups (see, for example, Bailey 1985; Massey 1987).

Comparing legalized migrants' earnings before and after legalization, Rivera Batiz (1999) further concluded that legalization led to significant wage growth for legalized migrants. Kossoudi and Cobb-Clark (2002), whose analysis uses data on legalized migrants from the LPS as well as data on a comparison group of Latino men, also find that IRCA had positive earnings effects for legalized migrants. Kossoudi and Clark suggest that much of the wage growth following legalization can be attributed to increased returns to human capital (also see Tienda and Singer 1995).

Post-IRCA research further suggests that the introduction of employer sanctions led to a decline in the earnings of migrant workers who were - or were suspected to be residing illegally in the US (see, for example, Massey and Gentsch 2015; Bansak 2005;

\footnotetext{
${ }^{2}$ A separate legalization programme for agriculture - the Special Agricultural Workers program - legalized an additional 1.3 million people who could prove 90 days of employment in the perishable crop sector in the year before IRCA, or more than 30 days in each of the previous three years (Papademetriou et al. 2004).
} 
Bansak and Rapheal 2001; Phillips and Massey 1999). Following IRCA, employers perceived an increased risk from employing illegal immigrants and therefore offered lower wages to migrants who were thought to be residing in the US without legal permission. Massey and Gentsch (2015, p. 496) argue that "... employers continued to hire undocumented migrants but transferred the costs and risks of doing so to the workers themselves in the form of lower pay".

Recent research suggests that the wage effects of legalization may have changed considerably over time and could now be much smaller than during the immediate aftermath of IRCA in the late 1980s and early 1990s. For example, using data from the New Immigrant Survey, Lofstrom et al. (2013) analyse the changes in wages of migrants who obtained legal permanent resident status in 2003 and who had previously worked in the US either without authorization or with authorization as temporary work permit holders. This analysis finds very limited or no wage gains from legalization, especially for lowskilled migrants. Any wage increases due to legalization are found to be limited to migrants with at least some college education. Lofstrom et al. argue that the lack of a large effect of legalization on wages can potentially be explained by the widespread use of false employment authorization documentation such as false Social Security numbers which, arguably, has undermined the threat and effectiveness of employer sanctions, especially in lower-skilled occupations. ${ }^{3}$ Employers employing higher skilled workers who are illegally resident potentially perceive a higher risk of detection and "reputational cost" of conviction, which may help explain the difference in the wage effects of legalization between high and lower-skilled workers,

A number of European countries - most notably Italy and Spain - have in recent years carried out regular large-scale legalization programmes for illegally resident migrant workers. However, to the best of my knowledge, there have not been any studies assessing the impact of these legalizations on the earnings of legalized migrants over time. There are a few studies that analyse the role of legal status as a determinant of migrants' wages in Europe. For example, using data from small sample surveys, Baldacci et al. (1999) find that

\footnotetext{
${ }^{3}$ The analysis of Lofstrom et al. (2013) covers a time period before the introduction of the "E-Verify" program which requires employers to check workers' right to work in the US via a free online system marinated by the federal government. E-Verify has been mandated in some but not all US states. Orrenius and Zavodny (2015) find that the introduction of E-Verify reduces the average hourly earnings among likely unauthorised male Mexican immigrants.
} 
illegal status imposes a significant wage penalty on migrants in Italy. The vast majority of illegally resident migrants in Italy is 'informally employed', i.e. without fully declaring their incomes and paying all the income taxes and national insurance contributions that would be required if they were formally employed (see, for example, Reyneri 1999). The concentration of illegal employment of migrants in the informal sector may be a key difference between Italy - and some other European countries - and the US where a significant share of illegal immigrants are working in the formal sector (e.g. by using fake or somebody else's social security numbers) and thus paying at least some payroll taxes (Papademetriou et al. 2004).

Theoretical considerations and existing empirical research on the relationship between immigration status and earnings thus suggest a variety of mechanisms through which "illegal residence" and/or "temporary legal residence" status may adversely impact on migrants' earnings. It is therefore reasonable to hypothesise that A8 workers who had already been working in the UK before $1^{\text {st }}$ May 2004, and who became EU nationals on that day, experienced an increase in earnings due to the change in legal (immigration) status. At the same time, it is important to emphasise that illegal residence or temporary legal residence cannot, as it is frequently done in public debates, be simply assumed to adversely affect migrants' outcomes in the labour market. In practice, the relationship between immigration status and earnings is likely to be highly specific to local contexts and labour markets. For example, in labour markets where the enforcement of immigration and employment laws is relatively low - as, arguably, it has been the case in the UK's flexible labour market - there can be many factors, unrelated to migrancy and immigration status, that make workers vulnerable in the workplace. Whether and how immigration status affects migrants' earnings are thus important questions for empirical analysis.

\section{Data}

This section discusses the sources and basic descriptive statistics of the data used in the subsequent empirical analysis of the impacts of immigration status on East European migrants' earnings in the UK. 


\subsection{Sources and methods of data collection}

Changing status, changing lives?

The primary source of data used in this paper is a survey of East European migrant workers in the UK, carried out within the Changing Status, Changing Lives? research project (henceforth CS project) at the Centre on Migration, Policy and Society (COMPAS) at the University of Oxford. The CS project included survey and in-depth interviews with more than 600 East European migrants, including workers from the A8 countries and other East European countries, working in low and medium skilled occupations in selected sectors of the UK economy: hospitality, construction, agriculture and the au-pair sector. The interviews were carried out in two waves: in April 2004 (i.e. just before EU enlargement) and 6-8 months later. The primary aim of the project was to explore the experiences of East European migrants in the UK - both at and beyond the workplace with a particular focus on the role of legal (immigration) status (for initial reports, see Anderson et al. 2006; and Spencer et al. 2007).

The analysis in this paper is based on a longitudinal sample of 221 migrants (henceforth "CS respondents") for whom information, including data on earnings, was obtained in both waves (i.e. before and after EU enlargement on $1^{\text {st }}$ May 2004). The sample includes 131 workers from A8 countries (the Czech Republic, Lithuania, Poland and Slovakia) and 90 workers from non-A8 countries in Eastern Europe (Bulgaria and the Ukraine). All respondents were residing and working - legally or illegally - in one of three sectors of the UK economy in April 2004: hospitality, construction and agriculture. All survey interviews were carried out face-to-face and in the language of the respondent. Except for those working in agriculture, the great majority of CS respondents were working in London.

As could be expected in a longitudinal survey about immigration status and earnings, the attrition rate was high. Only about a third of all the respondents interviewed before EU enlargement could be re-interviewed after enlargement. Among the 221 migrants in the sample used in this paper, 54 were interviewed in both wave1 and wave2. The remaining 167 respondents were interviewed in wave 2 only, but they were asked questions about their employment in the UK in April 2004 and at the time of their interview (6-8 months later). An effort was made to match respondents who were interviewed after EU 
enlargement only with the basic characteristics (including gender, age and nationality) of the respondents who could be interviewed in wave1 only.

The relatively short period (6-8 months) between April 2004 and the 'second wave' interviews means that 'recall bias', especially around key variables such as earnings, is unlikely to have been a major issue for migrants interviewed in wave 2 only. For the same reason, "return migration" between the two waves of interviews, which may in theory introduce selection effects and thus bias the results of the analysis, is likely to have been limited. It is reasonable to expect that a relatively small share of East European migrants who were present in the UK in April 2004 returned home (or left the UK for other countries) during the first 6-8 months after EU enlargement, a time when the UK experienced strong economic growth and high labour demand.

In the absence of a sample frame, the CS respondents were purposively selected rather than randomly chosen. As described above the sample of workers was constrained to the low-wage labour market and stratified based on nationality and sector of employment. Access was facilitated through a variety of informal techniques including gatekeepers such as community organizations and interviewers' contacts (for more detail about the methods used, see Anderson et al 2012). Consequently, I can not claim that the sample is representative of the wider population of East European migrants under consideration. The sample is, however, still very useful for an exploratory analysis of the impact of immigration status on earnings.

\section{Labour Force Survey}

Whenever possible and relevant, the paper also draws on data taken from the UK's Labour Force Survey (LFS). The LFS is a household survey carried out on a quarterly basis. About 60,000 households are surveyed every quarter. All LFS respondents are interviewed in five consecutive waves, with data on earnings collected in wave1 and wave 5 only. The LFS does not record immigration status but data on country of birth and nationality are available. As with all sample surveys that capture only a relatively small part of the population, analysis of sub-groups - such as East European migrants - is problematic due to small sample size (especially before EU enlargement). During March 2003 February 2004 (i.e. the year preceding EU enlargement), the LFS includes 48 migrants 
from A8 countries and 43 migrants from other (non-EU) East European countries ("non-EU EE"4) who were: born outside the UK, without EU citizenship, and resident in the UK for less than 5 years; in employment; and reporting earnings figures. Although immigration status is not recorded, most of the migrants in this sample can be expected to have legal temporary residence status in the UK. The minimum residence requirement for an application for permanent residence (“indefinite leave to remain") is five years.

\subsection{Descriptives}

This section provides background information about the personal characteristics, human capital, employment and immigration of the sample of $221 \mathrm{CS}$ respondents. All of the data presented below refer to respondents' situation in April 2004, i.e. just before EU enlargement. Table A1 in the Appendix contains detailed data about CS respondents in wave1 and wave2. Basic descriptives about East European migrants in the LFS (March 2003 - Feb 2004) and WRS (May-Sep 2004) are given in Tables A2 and A3, respectively.

\section{Personal characteristics and human capital in April 2004}

As shown in Table 1, A8 workers constituted just under 60 percent of the sample from the CS survey. About 38 percent of the total sample were women. The share of women among Bulgarians and Ukrainians (41 percent) was slightly higher than among A8 workers (35 percent). Data taken from the LFS and WRS suggest that the CS survey undersampled women, especially among A8 migrants. Women constitute 67 percent of A8 migrants in the LFS March 2003 - February 2004, and 47 percent of migrants registering with the WRS scheme during May-September 2004.

Table 1 here

The average age of CS respondents at the time of the wave1 interview was 27 (with no significant differences between A8 and other migrants). This is in line with data from the LFS (average age of East Europeans is 28) and the WRS (over 80 percent of A8 migrants aged 18-34). In the CS survey sample, Ukrainians and Bulgarians reported to

\footnotetext{
${ }^{4}$ The group of non-EU East European (non-EU EEA) countries includes Russia, Bulgaria, Romania, the Ukraine, Moldova, Bosnia, Macedonia, "other former Yugoslavia” and "other former USSR".
} 
financially support a significantly higher number of dependents than A8 respondents, 1.04 and 0.74 dependents, on average, respectively).

On average, CS respondents had completed 13 years of formal schooling, with A8 workers reporting 1.5 years more schooling, on average, than other respondents.

At the same time, A8 respondents reported less total work experience than Bulgarians and Ukrainians (6.1 years and 6.8 years, respectively). More than two thirds of CS respondents described their English speaking proficiency as "fluent" or "adequate" 5 . This share was slightly higher for A8 workers (70 percent) than for Bulgarian and Ukrainians. Most of the remaining respondents in the CS sample reported to have "basic" spoken English, with very few reporting to speak no English at all.

\section{Employment in April 2004}

As shown in Table 2, over 90 percent of CS respondents (and almost all Bulgarians and Ukrainians) were working, in April 2004, in the hospitality sector or in construction. All respondents in construction, and almost two third of respondents in agriculture, were male. In contrast, over two third of respondents employed in the hospitality sector were women. More than half of the migrants surveyed in the CS sample were working in occupations defined as requiring a relatively low level of skill. Just over a third were in skilled trades occupations (mainly working as kitchen chefs in hospitality or as carpenters in construction). For 16 percent of respondents, their primary job was a part-time job with fewer than 30 working hours per week.

A key difference between A8 migrants and other migrants in the CS sample is that Bulgarians and Ukrainians reported significantly higher rates of self employment and working for agencies than A8 respondents. The difference in self-employment rates is also reflected in labour force survey data (21\% self-employment among A8 migrants; and 26 percent self-employment among other Non-EU EE migrants).

Table 2 here

\footnotetext{
${ }^{5}$ Of course, these are self-assessments and we have no "objective" measurement.
} 
The average gross hourly earnings ${ }^{6}$ reported by CS respondents ( $£ 6.76$ for A8 migrants; and $£ 8.74$ for other migrants) are broadly in line with the corresponding data in the LFS ( $£ 6.54$ for A8 migrants; and $£ 7.65$ for other non-EU EE migrants) and the WRS (more than 80 percent of registered A8 workers earned between $£ 4.99-£ 5.90$ per hour). As expected, among the CS respondents earnings were lowest for employees in elementary occupations ( $£ 5.68$ per hour). Given the various complexities of minimum wage regulations (especially with respect to agriculture), the CS survey data are not detailed enough for an accurate assessment of the share of respondents receiving earnings below the minimum wage. Nevertheless, the survey data do suggest that a significant number of respondents were working at gross hourly pay rates that were close to - and, for a small number of cases, almost certainly below - the national minimum wage (NMW). In April 2004, the NMW in construction and hospitality was $£ 4.50$ per hour for workers aged 22 years and older; and $£ 3.80$ per hour for workers aged 18-21. In agriculture, the minimum wage for a "standard" worker in agriculture was $£ 5.15$ per hour for workers aged 19 and over; and $£ 4.38$ for 18 year olds. The rate for 'manual harvest workers' aged 19 or over was $£ 4.50$ per hour.

\section{Immigration status in April 2004}

The East European workers surveyed in the CS project were all fairly recent migrants. As of April 2004, CS respondents had spent an average of 20 months in the UK since their last entry for employment purposes, with very little difference between A8 and other migrants. More than two thirds of CS respondents arrived in the UK during January 2002 and April 2004.

There was great diversity in the self-reported immigration statuses of respondents in April 2004, prior to EU enlargement (see Table 3). The three major statuses reported by respondents were self-employed, student and "visa expired". There was, however, significant variation across sectors. For example, "student" was a major immigration status in hospitality (40 percent in that sector) but less so in other sectors. "Self-employed" was

\footnotetext{
${ }^{6} \mathrm{CS}$ respondents were given the option of reporting gross pay per hour, per week or per month. Only about half chose to report hourly figures. For the remainder, hourly gross pay had to be computed based on weekly working hours, and weekly or monthly gross pay reported. Given the nature of the CS survey, which targeted migrant workers employed legally or illegally in low-wage jobs in the UK, the majority of respondents reported pay verbally rather than by showing pay slips.
} 
the status most commonly reported by respondents in construction (60 percent), less so in hospitality (10 percent) and not at all by respondents in agriculture. Table A4 in the Appendix explains the major employment restrictions attached to each type of immigration status in Table 3.

Table 3 here

The survey data - which include the information on self-reported immigration status above and answers to various other questions pertaining to respondents' immigration status - can be used to construct an indicator of whether a respondent is "illegally resident" (i.e. without valid leave to remain) in the UK or not. Of the $210 \mathrm{CS}$ respondents in the sample for whom it was possible to make this assessment, at least 57 - 45 A8 migrants and 12 Ukrainians and Bulgarians - were illegally resident in April 2004. This includes 46 respondents who described their immigration status as either "visa expired" or "illegal"; and another 11 respondents classified as illegally resident because the interview data clearly suggested that they had either overstayed their visas or that their reported immigration status was simply impossible (e.g. respondents suggesting that they had entered and been working in the UK on SBS permits since before May 2003, when the SBS scheme was introduced). The relatively high incidence of illegal residence among the CS sample is not surprising, given that before EU enlargement the opportunities for legal employment of migrants in low-waged jobs were very limited.

It is important to note that the group of CS respondents classified as "illegally resident" excludes a significant number of respondents who are residing in the UK legally, but are working in violation of the employment restrictions attached to their immigration status - a situation that can be described as "semi-compliance" (Ruhs and Anderson 2008). 21 percent of CS respondents could be classified as semi-compliant in April 2004 (see Table A1 in the Appendix). This mainly includes migrants on student visas working significantly more than the 20 hours legally allowed during term time; and migrants on selfemployed visas who are in fact working as employees in the UK labour market.

Of course, the figures in Table 3 come with a number of caveats as asking migrants about their immigration status posed a number of challenges. The most fundamental problem was that, despite assurances of complete anonymity, respondents residing and/or 
working illegally could be expected to be reluctant to disclose information about their immigration circumstances. In order to address this issue, the relevant survey questions were carefully formulated and sequenced in order to encourage "matter of fact" answers rather than trying to induce, for example, blunt admissions of illegality. Interviewers were instructed to remain impassive and, if necessary, carefully prompt the various possible answers, none of which were intended to sound "better" or "more appropriate" than others. The aim was to establish as accurate a picture as possible about respondents' immigration circumstances by asking a set of questions whose answers could be checked for internal 'consistency'. The response rates to the survey questions about immigration were very high as very few respondents refused to answer the questions. This, arguably, suggests that the approach has worked reasonably well.

\section{Estimation methods and results}

EU enlargement on $1^{\text {st }}$ May 2004, and the UK Government's decision to grant A8 workers immediate free access to the British labour market, may be considered as a quasinatural experiment. It was an exogenous policy event that changed the legal immigration status of a selected group of East European migrants in the $\mathrm{UK}$ - namely, migrants from the A8 countries - while leaving the immigration status of other non-A8 migrants unaffected. There is now a significant literature on methods used to analyse data arising from natural and quasi-experiments in economics (for a review, see, for example, Meyer 1994). A common method used for policy analysis, and adopted in this paper, is the difference-indifference (DiD) estimator (see, for example, Card and Krueger 1994 and Connolly and Gregory 2002 on the impact of minimum wage on employment; Gruber 1994 on the impact of mandated maternity benefits on wages and employment; and Bansak and Raphael 2001 on the impact of IRCA on the earnings of migrants in the US).

The DiD estimation requires a "treatment group" of individuals affected by the policy and a "comparison group" of individuals unaffected by the policy. The DiD estimator $\left(\delta_{\mathrm{DD}}\right)$ is defined as the difference in average outcomes in the "treatment group" (T) before and after the treatment ( $t=0, t=1$, respectively) minus the difference in average outcomes in a comparison group $(\mathrm{C})$ before and after the treatment. 
(1) $\delta_{D D}=\left(\bar{Y}_{1}^{T}-\bar{Y}_{0}^{T}\right)-\left(\bar{Y}_{1}^{C}-\bar{Y}_{0}^{C}\right)$

Given pooled cross sectional data taken from before $(\mathrm{t}=0)$ and after $(\mathrm{t}=1)$ the treatment, the DiD can be estimated using simple regression as

(2) $y_{i t}=\alpha+\alpha_{1}$ treat $_{i t}+\alpha_{2}$ time $_{i t}+\delta_{D D}\left(\right.$ treat $_{i t} *$ time $\left._{i t}\right)+\varepsilon_{i t}$

where: "i" denotes the respondents and " $\mathrm{t}$ " denotes the time period; treat $=1$ if the respondent is in the treatment group, and 0 otherwise; time $=1$ if the observation is in the second time period (i.e. $\mathrm{t}=1$ ), and 0 otherwise; treat $*$ time $=1$ if the respondent is in the treatment group and the observation occurs in the second time period, and 0 otherwise; and $\varepsilon$ is a normally distributed error term.

Given panel data for two time periods, first differencing yields the simplified equation:

(3) $\Delta y_{i}=\alpha_{2}+\delta_{D D}$ treat $_{i}+\Delta \varepsilon_{i}$

where $\Delta \mathrm{y}_{\mathrm{i}}=\mathrm{y}_{\mathrm{i} 1}-\mathrm{y}_{\mathrm{i} 0}$ and $\Delta \varepsilon_{\mathrm{i}}=\varepsilon_{\mathrm{i} 1}-\varepsilon_{\mathrm{i} 0}$

Equation (3) can be easily extended to take account of time variant controls:

(4) $\Delta y_{i}=\alpha_{2}+\delta_{D D}$ treat $_{i}+\Delta \mathbf{x}_{i} \beta+\Delta \varepsilon_{i}$

where $\mathbf{x}_{\mathrm{i}}$ is a vector of time variant controls; $\Delta \mathrm{x}_{\mathrm{i}}=\mathrm{x}_{\mathrm{i} 1}-\mathrm{X}_{\mathrm{i} 0}$

Within this model, the effect of the policy change can thus simply be estimated by using OLS to regress the change in the outcome variable $\Delta y_{i}$ on the policy variable treat ${ }_{i}$ and on the change in the control variables $\Delta \mathbf{x}_{\mathrm{i}}$ (time-invariant controls for which $\Delta \mathrm{x}_{\mathrm{i}}=0$ cannot be included). A key advantage of the DiD model is that it eliminates time-constant unobserved heterogeneity. A critical assumption of the DiD estimator is that, in the absence of the treatment, the average change in the outcome would have been the same for both the treatment group and comparison group ("parallel trend assumption”). The estimator can thus only be applied when plausible comparison groups can be identified. 
This paper uses DiD estimations to explore whether and how migrants' earnings were affected by becoming an EU national. The treatment group consists of A8 migrants working in the UK both before and after EU enlargement. The comparison group includes other (white) East European migrants who were also working in the UK before and after enlargement, but whose countries of origin remained outside the EU after $1^{\text {st }}$ May 2004 (i.e. Ukrainians and Bulgarians in the CS sample). The treatment and comparison groups are made up of similar workers, engaged in similar occupations and exposed to the same general labour market conditions. This makes the DiD method particularly well suited to this study.

\subsection{Impacts of acquiring EU status}

As shown in Table 4, on average, gross hourly earnings of CS respondents increased by $£ 0.62$ ( $£ 0.54$ in real terms) between April 2004 (i.e. just before EU enlargement) and 6-8 months later (i.e. October-December 2004). This is an increase equivalent to 8.2 percent in nominal terms, and 7.3 percent in real terms. Part of this increase is likely to stem from the increase in the legal minimum wage on $1^{\text {st }}$ October 2004 (the main minimum rate increased by 7.7 percent from $£ 4.50$ to $£ 4.85$ an hour for workers aged 22 and over).

However, becoming an EU national may have played an important role, as the average growth in earnings for A8 respondents (11.8 percent in nominal terms) was significantly higher than that of respondents from the Ukraine and Bulgaria (4.3 percent). The unadjusted difference-in-difference estimate is $+£ 0.42$. As shown in Table A5 in the Appendix, the raw DiD estimate is slightly higher for men than for women (£0.47 and $£ 0.35$, respectively). It is significantly higher for respondents who were self-employed rather than working as employees in April 2004 ( $£ 0.92$ and $£ 0.37$, respectively).

Table 4 here

Table 5 reports the results from estimating equation (4) with the first difference of ln of gross hourly earnings as the dependent variable. The DiD estimate is given by the coefficient on the dummy variable "EU" (which is 1 for A8 nationals in wave 2, and 0 otherwise). The unadjusted DiD estimate for becoming an EU national is statistically 
significant $(\mathrm{t}=2.14)$ and the estimate remains significant after adding controls for occupation, sector of employment, self-employment, whether or not working for agency, English speaking proficiency and the number of dependents financially supported (see the estimated coefficients in bold in Table 5). Including controls, which marginally reduces the sample size, improves the fit of the equation.

The DiD estimates for becoming an EU national range from approximately 6.4 percent (model I) to 8 percent (model IV). Given the limitations of the sample used in this exploratory analysis, it is important to highlight that these estimates are associated with sizable confidence intervals. For example, the DiD estimate for becoming an EU national in model IV (8 percent) is associated with a 95 percent confidence interval that ranges from 2.3 percent to 13.7 percent.

An interesting additional finding of this analysis is that migrants employed by an employment agency appear to suffer from significant earnings penalties (around -15 percent, controlling for other factors) compared to migrants directly employed by businesses.

\subsection{Exploring the reasons for the positive impact of EU status on earnings}

For 38 percent (45 workers) of all A8 respondents (131) in the CS sample, becoming an EU national involved a legalization of their status in the UK (see Table 3). One may hypothesize that a considerable part of the positive impact of becoming an EU national on earnings identified above is likely to be a result of the legalization of a significant number of respondents. However, extending the DiD regression for EU status by including a variable that interacts EU status in wave 2 with illegal residence in April 2004 (not shown in Table 5) yields an insignificant coefficient on the interaction variable. Similarly, replacing the dummy for EU status with a dummy for "legalization" in the DiD regressions also results in an insignificant coefficient. These results suggest that the positive impact of EU status on earnings identified above cannot be explained by a legalization effect. Of course, the results on legalization need to be viewed with caution as they are critically dependent on the accuracy of our assessment of respondents' legal status in the UK. 
In the absence of any evidence of a significant legalization effect, how did acquiring EU status raise the earnings of A8 migrants in the UK? The analysis suggests that gaining the right to freely change jobs is likely to have been an important factor. There is a positive correlation between changing jobs and change in earnings between waves 1 and 2 (correlation coefficient $=0.34$ significant at $1 \%$ ). 35 percent of A8 nationals in the sample changed jobs after $1^{\text {st }}$ May 2004, but only 16 percent of Bulgarians and Ukrainians did.

Table 6 below reports the results of a probit regression that aims to analyse the determinants of the probability of changing jobs (between waves 1 and 2) of the workers in the CS sample. The dependent variable is whether or not workers have changed jobs and the dummy variable "EU" again measures the effects of acquiring EU status. The analysis includes a similar set of controls as used in the DiD analysis in the previous section (occupation, sector, type of employment, English speaking proficiency and number of dependents; see models I-V) but these controls now refer to April 2004 rather than to changes between the two waves of interviews. To explore the potential role of legalization in influencing the probability of changing jobs, model VI adds an interaction variable (EU*Legalization) to test whether illegal residence in April 2004 made any difference to the effect of gaining EU status on A8 migrants' likelihood of changing jobs.

The results in Table 6 show that acquiring EU status had a positive impact on the probability of changing jobs. The coefficient on the dummy variable "EU" is positive and statistically significant in all six models. The statistically significant and negative coefficient on the interaction effect between acquiring EU status and legalization in model VI suggests that legalization reduced the magnitude of the positive impact of acquiring EU status on the probability of changing jobs among A8 workers. Put differently, acquiring EU status had a larger positive impact on job changes among A8 workers who were legally resident in April 2004. The negative effect of legalization is confirmed by a separate probit regression (not shown) that replaces the 'EU dummy' with a 'legalization dummy' in model $\mathrm{V}$ of Table 6 . This regression yields a statistically significant and negative effect of legalization on the probability of changing jobs.

Table 6 here 
The positive impact of acquiring EU status on the probability of changing jobs was not the only way in which becoming an EU national led to a rise in the earnings of A8 migrants in the UK. To explore the existence of other mechanisms, I re-estimated the DiD models in Table 5 with an additional control variable that indicates whether or not the migrant changed jobs after EU enlargement. The results - not included here but available upon request - show that the impact of acquiring EU status on earnings remains statistically significant and positive even when controlling for actual job changes. ${ }^{7}$ In light of the discussion in section 2 of this paper, I argue that at least part of the explanation may be that A8 migrants' legal right to change jobs freely after EU enlargement reduced the monopsony power of their employers thus exerting upward pressure on migrants' earnings. In other words, acquiring the right to change jobs raised the earnings of A8 workers directly by enabling them to leave their current employers and change into higher paying jobs, and, I argue, also indirectly by increasing their bargaining power vis-à-vis their existing employers.

\subsection{Discussion}

The main finding of the empirical analysis in this paper is that acquiring EU status had a statistically significant and positive impact on the earnings of East European migrants in the UK. The data suggest that one of the mechanisms by which this positive impact was brought about was via workers gaining the right to freely change jobs and employers after EU enlargement. Legalization was not found to have a significant effect on changes in earnings.

In theory, if the UK Government's decision to lift all employment restrictions on A8 nationals on $1^{\text {st }}$ May 2004 was anticipated by the A8 workers analysed in this study, the results could be driven by anticipation and self-selection effects. In practice, this is unlikely

\footnotetext{
7 The data do not allow a reliable assessment of the relative importance of “changing jobs" vis-à-vis other mechanisms in explaining how acquiring EU status increased the earnings of A8 workers. This is partly because of the collinearity between "becoming an EU national" and "changing jobs" (as shown in Table 6) and the sizable confidence intervals around the estimated coefficients.
} 
to have been the case. Although most of the A8 migrants in the sample knew when they first arrived in the UK that they would become EU nationals on $1^{\text {st }}$ May 2004, they could not have known that they would also be given full and unrestricted access to the UK labour market. In the year preceding EU enlargement, there were extensive and heated public debates in the UK about whether to grant A8 workers full employment rights when they became EU nationals. Large parts of the mass media in particular exerted significant pressure on the Government to maintain restrictions on the employment of A8 workers after $1^{\text {st }}$ May 2004. In the end, the Government's decision to grant A8 workers full work rights was taken very late (about two months before EU enlargement) and took many people by surprise.

It is also possible - but I would argue unlikely - that the positive and significant DiD estimate primarily or partly reflects a negative impact of EU enlargement on those who remained non-EU nationals after $1^{\text {st }}$ May 2004 (i.e. Bulgarians and Ukrainians in the sample ${ }^{8}$ ). EU enlargement on $1^{\text {st }}$ May 2004 was accompanied by new Government policies aimed at reducing the illegal employment of migrants through increased employer sanctions. It is feasible that, following EU enlargement, employers perceived of the illegal employment of non-EU workers in low-skilled jobs as more risky than before EU enlargement, and therefore offered non-EU workers who were known or thought to be residing illegally lower wages and working conditions than before EU enlargement. For the same reasons, employers may have also substituted A8 workers for non-A8 workers making the latter an unsuitable comparison group for this study. However, although theoretically possible, these effects are unlikely to have played an important role. In the early and mid 2000s, the government's immigration policy was characterised by a rhetoric that was tough on the fight against illegal employment of migrants but enforcement in practice was very low (see Ruhs and Anderson 2008). Despite the new employer sanctions introduced in May 2004, employers would have had little reason to expect a sudden and significant increase in enforcement against illegality in the UK's migrant labour markets. Employers' recruitment and employment practices in the 6-8 months after EU enlargement (the period of this study) are therefore unlikely to have been significantly affected by the new employer sanctions introduced in May 2004.

\footnotetext{
${ }^{8}$ Bulgaria became a member of the EU on $1^{\text {st }}$ May 2007.
} 
The apparent insignificance of legalization as a determinant of the growth in earnings of A8 workers mirrors the results of recent studies about the earnings effects of legalization in the US (see e.g. Lofstrom et al. 2013). It may have a number of explanations. First, it may be a reflection of the relatively minor role of illegal status per se as a determinant of earnings in the UK's low-wage migrant labour market. Put differently, illegal residence may not put migrants in an inherently more disadvantageous position than temporary legal residence as a non-EU national, at least when compared to having EU status (also see Apgar 2015 who makes this point in the context of the US). When asked about the perceived impacts of immigration status in in-depth interviews, most of the migrants included in the wider CS study did not perceive illegality as directly leading to labour market outcomes that are worse than those of legally employed migrants (see Anderson et al. 2006). A simple earnings equation (not reported in this paper), using CS respondents in April 2004 with an expanded sample that includes migrants who were interviewed in wave1 only, suggests that illegal/legal status was not a significant determinant of earnings.

One cannot dismiss the possibility that migrants who are legally employed on temporary permits that tie them to specific employers feel less able to change employers and jobs than migrants employed illegally. If this is the case, it may help explain why the positive impact of acquiring EU status on the probability of changing jobs was larger for A8 workers who were legally resident in April 2004 (i.e. before EU enlargement) than for those who were illegally resident at that time.

As an alternative explanation for the insignificance of legalization effects on earnings identified in the analysis above, it is possible that formerly illegally resident A8 migrants may take a longer time to improve their post-enlargement outcomes in the UK labour market than A8 migrants who were employed legally before $1^{\text {st }}$ May 2004. This may have to do with access to different kinds of networks for the two groups. It is of course also possible that the results on the impacts of legalization are largely a reflection of limitations in the data, including the information about respondents' immigration status. 


\section{Conclusion}

This paper explores whether and how EU enlargement in May 2004 - and specifically the gaining of EU status - affected the earnings of East European migrants who were already working in the UK, legally or illegally, before $1^{\text {st }}$ May 2004. It is the first analysis of this issue in the UK and the EU more generally. Applying difference-indifference analysis to original and relatively small-scale survey data, the main finding of my exploratory analysis is that gaining EU status had a statistically significant and positive impact on the earnings of A8 workers in the UK, in the order of 6-8 percent over a period of 6-8 months.

The paper also investigated how this positive effect of becoming an EU national on earnings came about. The analysis suggests that acquiring the right to freely change employers played an important role. Gaining EU status was found to have a positive impact on the probability of changing jobs. Workers changing jobs after EU enlargement experienced significantly greater growth in earnings than workers who did not change jobs. At the same time, acquiring the right to change employers has strengthened the bargaining positon of A8 workers vis-à-vis their existing employers in the UK. This may help explain why acquiring EU status had a statistically significant and positive impact on earnings even when controlling for workers' job changes after EU enlargement.

The paper also considered the extent to which the positive earnings effect of becoming an EU national was driven by a legalization effect that some A8 migrants experienced on 1st May 2004. Based on the available data, the analysis found no significant impact of legalization on earnings. This is a more tentative result as it is based on analysis of a relatively small sample of workers whose legal status was not always easy to assess. Nevertheless, at a minimum, it does point to the importance of carefully distinguishing between the constraints and effects of different types of immigration status. The analysis in this paper challenges the popular assumption that legalization will, on its own, improve labour market outcomes of migrants. It also highlights the likely importance of the right to freely change jobs, which EU nationals and other migrants with permanent residence status enjoy but which remains limited under most temporary migration statuses. This is of direct relevance to current debates in the UK, US and many other high-income countries about the effects of legalization on the welfare of migrants. The analysis suggests that a legalization 
that grants migrants a residence status with the right to unrestricted access to the labour market is much more likely to succeed in improving migrants' labour market outcomes than a legalization programme that turns illegally resident migrants into temporary legal residents with restricted employment rights. This is an important piece of evidence and consideration for policymakers, especially (but not only) in Europe where the great majority of legalization programmes for migrant workers over the past 30 years have granted legalized migrants temporary work permits with restricted rights to employment (Chauvin et al 2013; Baldwin-Edwards and Kraler 2009).

In conclusion, it is important to emphasise three aspects of the analysis in this paper that may have implications for the generalizability of the results. First, the findings obtained in this analysis are based on a sample of migrant workers with particular characteristics that are not shared by some other groups of migrant workers. Perhaps most importantly, all migrants analysed in this paper were white, young and relatively recent arrivals from Eastern Europe. Given the potential significance of ethnicity as a determinant of earnings, it is possible that gaining EU status (or, more generally, acquiring permanent residence status) has different effects on migrants with different ethnicities. The differential impacts of legalization and, more generally, of a change in immigration status on the labour market outcomes of different groups of migrants constitute an important area for future research.

A second and related point is that the analysis focused on the impact of acquiring EU status on migrants who were working, before EU enlargement in May 2004, in low and medium skilled occupations in three sectors (agriculture, hospitality, construction and agriculture) of the UK economy. While the study's conclusions are likely to be relevant across a wide range of other occupations and sectors, it is possible that the significance and magnitude of the effects of acquiring EU status on earnings vary across workers employed in high- and low-skilled jobs (as Lofstrom et al. 2013 found in the context of their study of the effects of acquiring permanent residence status on migrants' wages in the US).

Third, the data analysed in this paper were collected in 2004 when the UK experienced relatively strong economic growth and labour demand. It is possible that the impact of acquiring EU status (or permanent residence) on migrants' earnings, especially via the mechanism of changing jobs, would be weaker during times of lower growth and 
labour demand such as in the years following the financial crash in 2008. It is an interesting task for future research to study the impacts of acquiring EU status on the labour market outcomes of migrants from more recent member states - such as Romania and Bulgaria which joined the EU in 2007 and whose citizens acquired full work rights in the UK in 2014 - and to compare these effects with the consequences for A8 workers identified in this paper.

Finally, as Britain leaves the European Union over the next few years, it is likely although not certain at this point in time (October 2016) - that 'free movement' migration to the UK will discontinue in its current form. The great majority of the EU migrants currently in the UK are expected to be given permanent residence status (thus retaining the right to free choice of employment in the UK), but some or potentially all new migrants from the EU countries will most likely require work permits (which usually tie workers to specific jobs) to take up legal employment in the UK. Whatever the 'post-Brexit' immigration regime that will eventually emerge in the UK, the analysis in this paper will remain highly relevant, specifically to questions about the effects of restricted employment rights on the labour market outcomes of migrant workers, and on the broader effects on the labour market and economy.

\section{References}

Aliverti, Anna (2013) 'Immigration Offences: Trends in Legislation and Criminal and Civil Enforcement', Migration Observatory briefing, COMPAS, University of Oxford, UK, July 2013

Anderson, B, Rogaly, B. and M. Ruhs (2012) 'Chasing ghosts: researching illegality in migrant labour markets', in Vargas-Silva, C. ed. (2012) Handbook of Research Methods in Migration, Edward Elgar

Anderson, B., Ruhs, M., Rogaly, B. and S. Spencer (2006) Fair enough? Central and East European migrants in low-wage employment in the UK, Report published by the Joseph Rowntree Foundation (JRF)

Apgar, L. (2015) 'Authorized status, limited returns. The labour market outcomes of temporary Mexican workers', EPI Briefing paper, Economic Policy Institute, Washington DC 
Bailey, T. (1985) 'The influence of legal status on the labor market impact of immigration, International Migration Review, vol. 19(2), pp. 220-238

Baldacci, E., Inglese, L. and S. Strozza (1999) 'Determinants of foreign workers' wages in two Italian regions with high illegal immigration', Labour, vol.13(3), pp 675-710

Baldwin-Edward, M. and A. Kraler eds. (2009) REGINE. Regularisations in Europe. Amsterdam: Pallas Publications

Bansak, C. (2005) 'The differential wage impact of the Immigration Reform and Control Act on Latino ethnic subgroups', Social Science Quarterly, vol. 86 (supplement), pp. 12791298

Bansak, C. and S. Raphael (2001) 'Immigration reform and the earnings of Latino workers: Do employer sanctions cause discrimination?', Industrial and Labor Relations Review, vol. 54(2), pp 275-295

Bell, B. (1997) 'The performance of immigrants in the United Kingdom: Evidence from the GHS', The Economic Journal, vol.107, pp 333-44

Blanchflower, D. and C. Shadforth (2009) 'Fear, unemployment and migration', Economic Journal, vol.119 (February), pp F136-F188

Calavita, K. (1992) Inside the State: The Bracero Program, Immigration and the INS, Routledge, New York

Card, D and A. Krueger (1994) 'Minimum wages and employment: A case study of the fast-food industry in New Jersey and Pennsylvania', The American Economic Review, vol. 84(4), pp 772-793

Chauvin, S., Garcés-Mascareñas, B. and A. Kraler (2013). "Working for legality: employment and migrant regularization in Europe." International Migration, 51 (6): 118131

Chiswick, B (1984) 'Illegal aliens in the United States labor market: An analysis of occupational attainment and earnings', International Migration Review, vol.18, pp 714-32

Clark, K. and S. Drinkwater (2008) 'The labour market performance of recent migrants', Oxford Review of Economic Policy, vol. 24(3), pp 495-516

Clark, K. and J. Lindley (2009) 'Immigrant assimilation pre and post labour market entry: evidence from the UK Labour Force Survey', Journal of Population Economics 22(1): 175198 
Connolly, S. and M. Gregory (2002) 'The national minimum wage and hours of work: Implications for low paid women', Oxford Bulletin of Economics and Statistics, vol.64, pp 607-631

DeGenova, N. (2002) 'Migrant 'illegality' and deportability in everyday life', Annual Review of Anthropology, vol. 31, pp419-47

Dickens, R. and A. McKnight (2008) 'Assimilation of migrants into the British labour market' Centre for Economic Performance occasional papers, CEPOP22. Centre for Economic Performance, LSE London, UK.

Devlin, C., Bolt, O., Patel, D., Harding, D. and Hussian, I. 'Impacts of migration on UK native employment: An analytical review of the evidence.' Home Office Occasional Paper 109, March 2014.

Drinkwater, S., Eade, J. and M. Garapich (2006) 'Poles Apart? EU Enlargement and the Labour Market Outcomes of Immigrants in the UK', Discussion Paper 2410, IZA, Bonn

Dustmann, C. and F. Fabbri (2005) 'Immigrants in the British Labour Market', Fiscal Studies, vol. 26(4), pp 423-470

Gilpin, N., Henty, M., Lemos, S., Portes, J. and C. Bullen (2006) 'The impact of free movement of workers from Central and Eastern Europe on the UK labour market', Department of Work and Pensions Working Paper No. 29, DWP, London

Gordon, I., Scanlon, K., Travers, T. and Christine Whitehead (2009) 'Economic impact on London and the UK of an earned regularisation of irregular migrants in the UK', Interim Report from LSE London

Gruber, J. (1994) 'The incidence of mandated maternity benefits', The American Economic Review, vol. 84(3), pp 622-641

Hotchkiss, J. and M Quispe-Agnoli (2013) 'The Expected Impact of State Immigration Legislation on Labor Market Outcomes.' Journal of Policy Analysis and Management 32 (1): 34-59

Institute for Public Policy Research (2006) 'Irregular migration in the UK', an IPPR FactFile, London

Kossoudji, S. and D. Cobb-Clark (2002) 'Coming out of the shadows: Learning about legal status and wages from the legalized population', Journal of Labor Economics, vol. 20(3), pp 598-628

Lemos, S. (2013) "Immigrant Economic Assimilation: Evidence from UK Longitudinal Data between 1978 and 2006", Labour Economics 24: 339-353 
Lemos, S.(2010) 'Labour Market Effects of Eastern European Migration in Wales', University of Leicester Department of Economics Working Paper No. 10/03, January 2010.

Lemos, S. and Portes, J.(2008)' The impact of migration from the new EU member states on native workers'. London: Department for Work and Pensions.

Lindley, J. (2002) 'Economic assimilation and the labour market performance of British refugees and economic migrants', Research paper 20002/06, Leverhulme Centre for Research on Globalisation and Economic Policy, University of Nottingham

Lofstrom, M., Hill, L. and J. Hayes (2013) 'Wage and mobility effects of legalization: Evidence from the new immigrant survey', Journal of Regional Science 53(1): 171-197

Lowell, B.L. and J. Avato (2007) 'The wages of skilled temporary migrants: Effects of visa pathways and job portability', Paper presented at a meeting of the Population Association of America, New York.

Manning, A. (2011) 'Imperfect competition in the labour market', in Ashenfelter, O. and D. Card (eds), Handbook of Labor Economics, Elsevier, Oxford

Massey, D. and K. Gentsch (2015) 'Undocumented migration to the United States and the wages of Mexican Immigrants', International Migration Review 48(2): 482-499

Massey, D. (1987) 'Do undocumented migrants earn lower wages than legal immigrants? New evidence from Mexico', International Migration Review, vol. 21(2), pp 236-274

Meyer, B. (1994) 'Natural and quasi-experiments in economics', Technical Working Paper No. 170, NBER, Cambridge, MA

Migration Advisory Committee (2012)' Analysis of the Impacts of Migration’, MAC, London

Migration Advisory Committee (2009) Review of the UK's transitional measures for nationals of member states that acceded to the European Union in 2004, MAC, London

Office for National Statistics (2015) 'UK Labour Market Statistical Bulletin', August 2015, available at http://www.ons.gov.uk/ons/dep171778_412021.pdf

Orrenius, P. and M. Zavodny (2015) 'The impact of E-Verify mandates on labor market outcomes', Southern Economic Journal 81(4): 947959

Papademetriou, D., O'Neil, K. and M. Jachimowicz (2004) 'Observations on regularization and the labor market performance of unauthorized and regularized immigrants', Paper prepared for the European Commission, DG Employment and Social Affairs, Brussels 
Phillips, J. and D. Massey (1999) 'The new labor market: Immigrants and wages after IRCA', Demography, vol. 36(2), pp 233-246

Reyneri, E. (1999) 'The mass legalization of migrants in Italy: Permanent or temporary emergence from the underground economy?', in Immigrants in the Informal Economy in Southern Europe, edited by Baldwin-Edwards, M. and J. Arango, Frank Cass, London

Rivera-Batiz, F. (1999) 'Undocumented workers in the labor market: An analysis of the earnings of legal and illegal Mexican immigrants in the United States', Journal of Population Economics, vol. 12, pp 91-116

Ruhs, M. and B. Anderson (2008) 'The origins and functions of illegality in migrant labour markets: An analysis of migrants, employers and the state in the UK', COMPAS Working Paper No. WP-06-30a, Oxford

Shields, M. and S. Wheatley Price (1998) 'The earnings of male immigrants in England: Evidence from the QLFS', Applied Economics, vol. 30, pp 1157-1168

Spencer, S., Ruhs, M., Anderson, B. and B. Rogaly (2007) Migrants' lives beyond the workplace: The experiences of East and Central Europeans in the UK, Joseph Rowntree Foundation, London

Stark, O. (2007) 'Work effort, moderation in expulsion, and illegal migration', Review of Development Economics 11(4): 585-590

Taylor, E. (1992) 'Earnings and mobility of legal and illegal immigrant workers in agriculture', American Journal of Agricultural Economics, vol. 74(4), pp 889-896

Tienda, M. and A. Singer (1995) 'Wage mobility of undocumented workers in the United States', International Migration Review, vol. 29(1), pp 112-138

Trade Union Congress (2006) 'Working on the edge: A TUC report on agency workers', TUC, London

Trade Union Congress (2007) 'Agency workers: Counting the cost of flexibility, TUC'

UK Home Office (2009) Accession Monitoring Report, December 2004 - March 2009, Home Office, London

UK Home Office (2006), Control of Immigration: Statistics 2005, Command Paper

UK Home Office (2005) Illegal Working taskforce Regulatory Impact Assessment from Immigration, Asylum and nationality Bill, Published on 22 June 2005

Woodbridge, J. (2005) 'Sizing the unauthorised (illegal) migrant population in the United Kingdom in 2001', Home Office Online Report 29/05, London 


\section{TABLES}

Table 1 Survey respondents by citizenship and gender, April 2004

\begin{tabular}{lccccccccc}
\hline & CZE & LTU & POL & SVK & BGR & UKR & Total & A8 & NA8 \\
\hline Male & 13 & 28 & 26 & 18 & 25 & 28 & 138 & 85 & 53 \\
Female & 9 & 14 & 15 & 8 & 14 & 23 & 83 & 46 & 37 \\
Total & 22 & 42 & 41 & 26 & 39 & 51 & 221 & 131 & 90 \\
\hline
\end{tabular}

Source: Survey interviews with migrant workers, CS project

Notes: "A8" indicates nationals of A8 countries; "NA8" indicates respondents from non-A8 countries (i.e.

Bulgarians and Ukrainians).

Table 2: Characteristics of employment of CS respondents, April 2004

\begin{tabular}{|c|c|c|c|}
\hline & A8 & NA8 & Total \\
\hline \multicolumn{4}{|l|}{ Sector or employment, col\% } \\
\hline Hospitality & $45 \%$ & $50 \%$ & $47 \%$ \\
\hline Construction & $36 \%$ & $48 \%$ & $41 \%$ \\
\hline Agriculture & $19 \%$ & $2 \%$ & $12 \%$ \\
\hline \multicolumn{4}{|l|}{ Occupation, col\% } \\
\hline Occupation cat. 1 (Managers etc.) ${ }^{1}$ & $7 \%$ & $6 \%$ & $6 \%$ \\
\hline Occupation cat. 2 (Skilled trades) ${ }^{2}$ & $37 \%$ & $32 \%$ & $35 \%$ \\
\hline Occupation cat. 3 (Elementary occ. etc.) ${ }^{3}$ & $56 \%$ & $62 \%$ & $59 \%$ \\
\hline Self-employed (employment relationship ${ }^{4}$ ), col\% & $18 \%$ & $37 \%$ & $26 \%$ \\
\hline Working for employment business ("agency"), col\% & $18 \%$ & $32 \%$ & $23 \%$ \\
\hline Working part-time, i.e. fewer than 30 hours pw, col\% & $16 \%$ & $15 \%$ & $16 \%$ \\
\hline Gross hourly pay in $£$, mean (and sd) & $\begin{array}{l}£ 6.76 \\
(2.54)\end{array}$ & $\begin{array}{l}£ 8.74 \\
(4.99)\end{array}$ & $\begin{array}{l}£ 7.57 \\
(3.85)\end{array}$ \\
\hline
\end{tabular}

Source: Survey interviews with migrant workers and au-pairs, CS project

Notes:

${ }^{1}$ Occupation category 1 includes managers and senior officials; professional occupations; associate professional and technical occupations; and administrative and secretarial occupations.

${ }^{2}$ Occupation category 2 includes skilled trades occupations.

${ }^{3}$ Occupation category 3 includes personal service occupations; sales and customer service occupations; process, plant and machinery operatives; and elementary occupations.

${ }^{4}$ Based on respondents' descriptions of their employment relationships rather than immigration status.

Respondents' various self-reported immigration statuses - which includes the status of self-employed - are given in Table 3. 
Table 3: Self-reported immigration status and imputed compliance of CS respondents, April 2004

\begin{tabular}{lccc}
\hline Group: & A8 & $\begin{array}{c}\text { NA8 } \\
\text { column } \%\end{array}$ & Total \\
Units: & & & \\
\hline Self-reported immigration status: & $n=131$ & $n=90$ & $n=221$ \\
Observations $(n)$ & $25 \%$ & $34 \%$ & $29 \%$ \\
$\quad$ Self-employed & $19 \%$ & $34 \%$ & $25 \%$ \\
Student & $32 \%$ & $6 \%$ & $21 \%$ \\
"Visa expired" & $4 \%$ & $10 \%$ & $6 \%$ \\
"Don't know" & $5 \%$ & $2 \%$ & $4 \%$ \\
Seasonal Agricultural Worker Scheme permit & $3 \%$ & $6 \%$ & $4 \%$ \\
Dependent & $3 \%$ & & $2 \%$ \\
Au-pair & & $2 \%$ & $1 \%$ \\
Sector-based Scheme permit & $1 \%$ & & $0.5 \%$ \\
Asylum seeker & $1 \%$ & & $0.5 \%$ \\
"Illegal" & $8 \%$ & $6 \%$ & $7 \%$ \\
Other & & & \\
& & & \\
Imputed "compliance": & $n=125$ & $n=85$ & $n=210$ \\
Observations $(n)$ & $34 \%$ & $13 \%$ & $26 \%$ \\
$\quad$ Illegally resident ("non-compliant") & &
\end{tabular}

Source: Survey interviews with migrant workers, CS project

Note: Percent totals do not always add up to $100 \%$ due to rounding

Table 4: Gross hourly pay ( $£$ ) of CS respondents, before and after EU enlargement in May 2004

\begin{tabular}{lccc}
\hline & $\mathrm{A} 8$ & $\mathrm{NA} 8$ & Total \\
\hline Before enlargement & 6.76 & 8.74 & 7.57 \\
$\quad$ sd & $(2.54)$ & $(4.99)$ & $(3.85)$ \\
& & & \\
After enlargement & 7.56 & 9.12 & 8.19 \\
$\quad$ sd & $(2.84)$ & $(5.03)$ & $(3.95)$ \\
Change & 0.80 & 0.38 & 0.62
\end{tabular}

Observations: $\quad 131 \quad 90 \quad 221$

Source: Survey interviews with migrant workers, CS project 
Table 5: Difference-in-difference estimates (OLS) for becoming an EU national

Dep. Variable: Ln gross hourly pay (estimated in first differences; t-values in parentheses)

\begin{tabular}{|c|c|c|c|c|c|c|c|c|c|c|}
\hline & \multicolumn{2}{|l|}{ I } & \multicolumn{2}{|l|}{ II } & \multicolumn{2}{|c|}{ III } & \multicolumn{2}{|c|}{ IV } & \multicolumn{2}{|c|}{$\mathbf{V}$} \\
\hline constant & $0.045 * *$ & $(2.00)$ & $0.043^{*}$ & (1.93) & 0.034 & (1.56) & 0.023 & $(1.03)$ & 0.008 & $(0.29)$ \\
\hline $\mathbf{E U}\left(\boldsymbol{\delta}_{\mathrm{DD}}\right)$ & $0.064 * *$ & (2.14) & $0.072 * *$ & (2.49) & $0.067 * *$ & (2.39) & $0.08 * * *$ & (2.80) & $0.074 * *$ & (2.49) \\
\hline Managers etc. & & & $0.280 * * *$ & $(3.51)$ & 0.140 & $(1.57)$ & $0.249 * * *$ & $(2.71)$ & $0.252 * * *$ & $(2.69)$ \\
\hline Skilled trades & & & 0.039 & $(0.62)$ & 0.100 & $(1.43)$ & 0.021 & $(0.27)$ & 0.021 & $(0.26)$ \\
\hline \multicolumn{11}{|l|}{ Elem. occ. etc. } \\
\hline Agriculture & & & & & 0.038 & $(0.27)$ & -0.03 & $(-0.20)$ & -0.03 & $(-0.22)$ \\
\hline Construction & & & & & 0.025 & $(0.20)$ & 0.044 & $(0.34)$ & 0.066 & $(0.50)$ \\
\hline Sales and retail & & & & & 0.095 & $(0.44)$ & 0.012 & $(0.06)$ & 0.006 & $(0.03)$ \\
\hline Other sector & & & & & $0.282 * * *$ & $(3.49)$ & 0.118 & $(1.24)$ & 0.113 & (1.16) \\
\hline \multicolumn{11}{|l|}{ Hospitality } \\
\hline Self-employed & & & & & & & 0.054 & $(0.83)$ & 0.492 & $(0.74)$ \\
\hline Work for agency & & & & & & & $-0.16 * * *$ & $(-3.16)$ & $-0.15 * * *$ & $(-2.91)$ \\
\hline Eng. Speak. prof. & & & & & & & & & 0.038 & (1.29) \\
\hline No. dependents & & & & & & & & & 0.11 & $(0.59)$ \\
\hline Ad. $\mathrm{R}^{2}$ & 0.02 & & 0.07 & & 0.12 & & 0.1 & & 0 . & \\
\hline Observations & 221 & & 215 & & 215 & & 20 & & 15 & \\
\hline
\end{tabular}

Notes: $* * *$, and $* * *$ indicate statistical significance at $10 \%, 5 \%$ and $1 \%$, respectively. 
Table 6: Probit estimates of the probability of changing primary jobs between April 2004 (i.e. before EU enlargement) and Nov 2004 (i.e. after EU enlargement), marginal effects, z-values in parentheses

\begin{tabular}{|c|c|c|c|c|c|c|c|c|c|c|c|c|}
\hline & \multicolumn{2}{|l|}{ I } & \multicolumn{2}{|c|}{ II } & \multicolumn{2}{|c|}{ III } & \multicolumn{2}{|c|}{ IV } & \multicolumn{2}{|c|}{$\mathbf{V}$} & \multicolumn{2}{|c|}{ VI } \\
\hline $\mathrm{EU}$ & $0.197 * * *$ & $(3.15)$ & $0.201 * * *$ & $(3.19)$ & $0.204 * * *$ & $(3.15)$ & $0.202 * * *$ & $(2.94)$ & $0.205^{* * *}$ & $(2.90)$ & $0.28 * * *$ & $(3.67)$ \\
\hline Managers etc. & & & -0.08 & $(-0.60)$ & -0.09 & $(-0.74)$ & -0.11 & $(-0.84)$ & -0.16 & $(-1.11)$ & -0.17 & $(-1.09)$ \\
\hline Skilled trades & & & -0.02 & $(-0.36)$ & 0.003 & $(0.05)$ & 0.044 & $(0.58)$ & 0.04 & $(0.50)$ & 0.07 & $(0.78)$ \\
\hline \multicolumn{13}{|l|}{ Elem. occ. etc. } \\
\hline Agriculture & & & & & -0.07 & $(-0.68)$ & -0.11 & $(-1.11)$ & -0.11 & $(-1.08)$ & -0.10 & $(-0.84)$ \\
\hline Construction & & & & & -0.06 & $(-0.75)$ & -0.02 & $(-0.28)$ & -0.03 & $(-0.32)$ & -0.06 & $(-0.70)$ \\
\hline \multicolumn{13}{|l|}{ Hospitality } \\
\hline Self-employed & & & & & & & $-0.21 * *$ & $(-2.31)$ & $-0.21 * *$ & $(-2.25)$ & $-0.28 * * *$ & $(-2.88)$ \\
\hline Work for agency & & & & & & & 0.09 & $(1.21)$ & 0.09 & $(1.23)$ & 0.04 & $(0.52)$ \\
\hline Eng. Speak. prof. & & & & & & & & & 0.01 & $(0.14)$ & 0.04 & $(0.46)$ \\
\hline No. dependents & & & & & & & & & 0.01 & $(0.39)$ & 0.01 & $(0.56)$ \\
\hline EU*Legalization & & & & & & & & & & & $-0.33 * * *$ & $(-3.61)$ \\
\hline Log-likelihood & \multicolumn{2}{|c|}{-123.2} & \multicolumn{2}{|c|}{-118.3} & \multicolumn{2}{|c|}{-117.9} & \multicolumn{2}{|c|}{-113.45} & \multicolumn{2}{|c|}{-110.45} & \multicolumn{2}{|c|}{-97.15} \\
\hline Pseudo $\mathrm{R}^{2}$ & \multicolumn{2}{|c|}{0.039} & \multicolumn{2}{|c|}{0.043} & \multicolumn{2}{|c|}{0.046} & \multicolumn{2}{|c|}{0.073} & \multicolumn{2}{|c|}{0.07} & \multicolumn{2}{|c|}{0.14} \\
\hline Observations & \multicolumn{2}{|l|}{221} & \multicolumn{2}{|c|}{216} & \multicolumn{2}{|c|}{216} & \multicolumn{2}{|c|}{212} & \multicolumn{2}{|c|}{205} & \multicolumn{2}{|c|}{190} \\
\hline
\end{tabular}

Notes: Except for the interaction between "EU" and "Legalization", all controls refer to April 2004 (i.e. wave1 before EU enlargement); *,**, and *** indicate statistical significance at $10 \%, 5 \%$ and $1 \%$, respectively 
Table A1: CS respondents: Personal characteristics, human capital, employment and immigration

\begin{tabular}{|c|c|c|c|c|c|c|}
\hline \multirow{3}{*}{$\begin{array}{l}\text { Group: } \\
\text { Number of observations }{ }^{1}:\end{array}$} & \multicolumn{3}{|c|}{ BEFORE } & \multicolumn{3}{|c|}{ AFTER } \\
\hline & A8 & NA8 & Total & A8 & NA8 & Total \\
\hline & 131 & 90 & 221 & 131 & 90 & 221 \\
\hline \multicolumn{7}{|c|}{ CHARACTERISTICS } \\
\hline Citizenship $\left(\operatorname{col} \%^{2}\right)$ & & & & & & \\
\hline Czech Republic & $17 \%$ & & $10 \%$ & & & \\
\hline Lithuania & $32 \%$ & & $19 \%$ & & & \\
\hline Poland & $31 \%$ & & $19 \%$ & & & \\
\hline Slovakia & $20 \%$ & & $12 \%$ & & & \\
\hline Bulgaria & & $43 \%$ & $18 \%$ & & & \\
\hline Ukraine & & $57 \%$ & $23 \%$ & & & \\
\hline Female (col\%) & $35 \%$ & $41 \%$ & $38 \%$ & & & \\
\hline $\begin{array}{l}\text { Dependents supported (mean) } \\
\text { sd }\end{array}$ & $\begin{array}{c}0.74 \\
(1.40)\end{array}$ & $\begin{array}{c}1.04 \\
(1.30)\end{array}$ & $\begin{array}{c}0.87 \\
(1.37)\end{array}$ & $\begin{array}{c}0.64 \\
(1.09)\end{array}$ & $\begin{array}{l}1.01 \\
(1.29)\end{array}$ & $\begin{array}{c}0.79 \\
(1.19)\end{array}$ \\
\hline $\begin{array}{l}\text { Age (years) } \\
\text { sd }\end{array}$ & $\begin{array}{l}27.37 \\
(6.10)\end{array}$ & $\begin{array}{l}27.59 \\
(6.46)\end{array}$ & $\begin{array}{l}27.45 \\
(6.23)\end{array}$ & $\begin{array}{l}27.95 \\
(6.07)\end{array}$ & $\begin{array}{l}28.25 \\
(6.50)\end{array}$ & $\begin{array}{l}28.07 \\
(6.22)\end{array}$ \\
\hline
\end{tabular}

HUMAN CAPITAL

\begin{tabular}{|c|c|c|c|c|c|c|}
\hline $\begin{array}{l}\text { Schooling (years) } \\
\text { sd }\end{array}$ & $\begin{array}{l}13.41 \\
(2.83)\end{array}$ & $\begin{array}{l}11.86 \\
(3.70)\end{array}$ & $\begin{array}{l}12.81 \\
(3.28)\end{array}$ & & & \\
\hline \multicolumn{7}{|l|}{ English speaking proficiency (col\%) } \\
\hline fluent & $18 \%$ & $27 \%$ & $22 \%$ & & & \\
\hline adequate & $52 \%$ & $36 \%$ & $45 \%$ & & & \\
\hline basic only & $26 \%$ & $35 \%$ & $30 \%$ & & & \\
\hline none & $4 \%$ & $2 \%$ & $3 \%$ & & & \\
\hline $\begin{array}{l}\text { Work experience - total (months) } \\
\text { sd }\end{array}$ & $\begin{array}{l}73.55 \\
(81.95)\end{array}$ & $\begin{array}{l}81.33 \\
(73.97)\end{array}$ & $\begin{array}{c}76.36 \\
(78.93)\end{array}$ & & & \\
\hline \multicolumn{7}{|c|}{ EMPLOYMENT } \\
\hline $\begin{array}{l}\text { Gross hourly pay }(\mathfrak{f}) \\
\text { sd }\end{array}$ & $\begin{array}{l}6.76 \\
(2.54)\end{array}$ & $\begin{array}{c}8.74 \\
(4.99)\end{array}$ & $\begin{array}{c}7.57 \\
(3.85)\end{array}$ & $\begin{array}{l}7.56 \\
(2.84)\end{array}$ & $\begin{array}{c}9.12 \\
(5.03)\end{array}$ & $\begin{array}{c}8.19 \\
(3.95)\end{array}$ \\
\hline $\begin{array}{l}\text { Working hours per week } \\
\text { sd }\end{array}$ & $\begin{array}{c}42.80 \\
(13.40)\end{array}$ & $\begin{array}{l}39.06 \\
(10.73)\end{array}$ & $\begin{array}{c}41.29 \\
(12.50)\end{array}$ & $\begin{array}{c}42.41 \\
(12.94)\end{array}$ & $\begin{array}{c}38.95 \\
(12.09)\end{array}$ & $\begin{array}{c}41.01 \\
(12.69)\end{array}$ \\
\hline \multicolumn{7}{|l|}{ Sector or employment (col\%) } \\
\hline Hospitality & $45 \%$ & $50 \%$ & $47 \%$ & $41 \%$ & $48 \%$ & $43 \%$ \\
\hline Construction & $36 \%$ & $48 \%$ & $41 \%$ & $34 \%$ & $48 \%$ & $40 \%$ \\
\hline Agriculture & $19 \%$ & $2 \%$ & $12 \%$ & $18 \%$ & & $11 \%$ \\
\hline Other & & & & $8 \%$ & $4 \%$ & $7 \%$ \\
\hline
\end{tabular}

Source: CS survey, COMPAS

Notes: ${ }^{1} \ldots$ the number of observations varies slightly across variables due to missing data; ${ }^{2}$... Percent totals do not always add up to $100 \%$ due to rounding 
Table A1 (contd.): CS respondents: Personal characteristics, human capital, employment and immigration

\begin{tabular}{|c|c|c|c|c|c|c|}
\hline & \multicolumn{3}{|c|}{ BEFORE } & \multicolumn{3}{|c|}{ AFTER } \\
\hline & A8 & NA8 & Total & A8 & NA8 & Total \\
\hline Occupation (col\%) & & & & & & \\
\hline Occ. cat. 1 (Managers etc.) & $7 \%$ & $6 \%$ & $6 \%$ & $11 \%$ & $7 \%$ & $9 \%$ \\
\hline Occ. cat. 2 (Skilled trades) & $37 \%$ & $32 \%$ & $35 \%$ & $35 \%$ & $35 \%$ & $35 \%$ \\
\hline Occ. cat. 3 (Elementary occ. etc.) & $56 \%$ & $62 \%$ & $59 \%$ & $54 \%$ & $58 \%$ & $56 \%$ \\
\hline Self-employed (col\%) & $18 \%$ & $37 \%$ & $26 \%$ & $18 \%$ & $42 \%$ & $28 \%$ \\
\hline Working for recruitment agency (col\%) & $18 \%$ & $32 \%$ & $23 \%$ & $17 \%$ & $27 \%$ & $21 \%$ \\
\hline Working part-time, $<30$ hours (col\%) & $16 \%$ & $15 \%$ & $16 \%$ & $16 \%$ & $19 \%$ & $17 \%$ \\
\hline Primary job in London (col\%) & $70 \%$ & $92 \%$ & $79 \%$ & $72 \%$ & $94 \%$ & $81 \%$ \\
\hline $\begin{array}{l}\text { Number of jobs, as of April } 2004 \\
\text { sd }\end{array}$ & $\begin{array}{c}1.10 \\
(0.32)\end{array}$ & $\begin{array}{c}1.02 \\
(0.15)\end{array}$ & $\begin{array}{l}1.06 \\
(0.27)\end{array}$ & $\begin{array}{c}1.19 \\
(0.47)\end{array}$ & $\begin{array}{c}1.04 \\
(0.21)\end{array}$ & $\begin{array}{l}1.13 \\
(0.39)\end{array}$ \\
\hline
\end{tabular}

\section{IMMIGRATION}

\begin{tabular}{|c|c|c|c|c|c|c|}
\hline $\begin{array}{l}\text { Time in UK since last entry to UK (months) } \\
\text { sd }\end{array}$ & $\begin{array}{c}19.15 \\
(19.06)\end{array}$ & $\begin{array}{l}21.76 \\
(17.90)\end{array}$ & $\begin{array}{c}20.13 \\
(18.63)\end{array}$ & $\begin{array}{c}26.68 \\
(18.960\end{array}$ & $\begin{array}{c}30.23 \\
(17.86)\end{array}$ & $\begin{array}{c}28.02 \\
(18.59)\end{array}$ \\
\hline \multicolumn{7}{|l|}{ Year of last entry to UK (col\%) } \\
\hline 2004 & $27 \%$ & $13 \%$ & $21 \%$ & & & \\
\hline 2003 & $36 \%$ & $36 \%$ & $36 \%$ & & & \\
\hline 2002 & $10 \%$ & $22 \%$ & $15 \%$ & & & \\
\hline 2001 & $12 \%$ & $14 \%$ & $13 \%$ & & & \\
\hline $2000-1997$ & $15 \%$ & $15 \%$ & $15 \%$ & & & \\
\hline \multicolumn{7}{|l|}{ Self-reported immigration status (col\%) } \\
\hline EU national & & & & $100 \%$ & & $59 \%$ \\
\hline Self-employed & $25 \%$ & $34 \%$ & $29 \%$ & & $33 \%$ & $14 \%$ \\
\hline Student & $19 \%$ & $34 \%$ & $25 \%$ & & $30 \%$ & $12 \%$ \\
\hline "Visa expired" & $32 \%$ & $6 \%$ & $21 \%$ & & $10 \%$ & $4 \%$ \\
\hline "Don't know" & $4 \%$ & $10 \%$ & $6 \%$ & & $8 \%$ & $3 \%$ \\
\hline Seasonal Agricultural Worker Scheme & $5 \%$ & $2 \%$ & $4 \%$ & & $1 \%$ & $1 \%$ \\
\hline Dependent & $3 \%$ & $6 \%$ & $4 \%$ & & $6 \%$ & $2 \%$ \\
\hline Au-pair & $3 \%$ & & $2 \%$ & & & \\
\hline Sector-based Scheme permit & & $2 \%$ & $1 \%$ & & $1 \%$ & $1 \%$ \\
\hline Asylum seeker & $1 \%$ & & $0.5 \%$ & & & \\
\hline "Illegal" & $1 \%$ & & $0.5 \%$ & & & \\
\hline Other & $8 \%$ & $6 \%$ & $7 \%$ & & $11 \%$ & $4 \%$ \\
\hline Non-compliant ("illegally resident")(col\%) & $34 \%$ & $13 \%$ & $26 \%$ & $0 \%$ & $17 \%$ & $7 \%$ \\
\hline Semi-compliant (col\%) & $17 \%$ & $28 \%$ & $21 \%$ & & $21 \%$ & \\
\hline
\end{tabular}

Source: CS survey, COMPAS

Notes: ${ }^{l} \ldots$ the number of observations varies slightly across variables due to missing data; ${ }^{2} \ldots$ Percent totals do not always add up to $100 \%$ due to rounding 
Table A2: Personal characteristics and employment of East European migrants without EU citizenship and fewer than 5 years of residence in the UK, UK Labour Force Surveys March 2003- Feb 2004 (waves 1 and 5)

\begin{tabular}{|c|c|c|c|}
\hline Group: & A8 & Non-EU EE & Total \\
\hline Observations: & 91 & 69 & 160 \\
\hline \multicolumn{4}{|c|}{ PERSONAL CHARACTERISTICS } \\
\hline \multicolumn{4}{|l|}{ Nationality A8 (col\%): } \\
\hline Poland & $34 \%$ & & $19 \%$ \\
\hline Slovakia & $21 \%$ & & $12 \%$ \\
\hline Czech Republic & $13 \%$ & & $7 \%$ \\
\hline Lithuania & $13 \%$ & & $7 \%$ \\
\hline Hungary & $12 \%$ & & $7 \%$ \\
\hline Latvia & $4 \%$ & & $2 \%$ \\
\hline Estonia & $2 \%$ & & $1 \%$ \\
\hline \multicolumn{4}{|l|}{ Nationality Non-EU EE (col\%): } \\
\hline Russia & & $30 \%$ & $13 \%$ \\
\hline Bulgaria & & $19 \%$ & $8 \%$ \\
\hline Other form. Yugoslavia & & $16 \%$ & $7 \%$ \\
\hline Romania & & $12 \%$ & $5 \%$ \\
\hline Ukraine & & $7 \%$ & $3 \%$ \\
\hline Moldova & & $6 \%$ & $2 \%$ \\
\hline Other former USSR & & $4 \%$ & $2 \%$ \\
\hline Bosnia & & $3 \%$ & $1 \%$ \\
\hline Macedonia & & $3 \%$ & $1 \%$ \\
\hline Female (col\%) & $67 \%$ & $56 \%$ & $62 \%$ \\
\hline Married (col\%) & $33 \%$ & $61 \%$ & $45 \%$ \\
\hline Age (years) & 27.29 & 29.29 & 28.15 \\
\hline \multicolumn{4}{|c|}{ EMPLOYMENT } \\
\hline Self-employed (col\%) & $21 \%$ & $26 \%$ & $23 \%$ \\
\hline Working part-time (col\%) & $43 \%$ & $30 \%$ & $38 \%$ \\
\hline Working in London ( $\mathrm{col} \%)$ & $52 \%$ & $39 \%$ & $46 \%$ \\
\hline \multicolumn{4}{|l|}{ Economic sector (col\%) } \\
\hline Construction & $15 \%$ & $20 \%$ & $17 \%$ \\
\hline Hotels and restaurants & $24 \%$ & $19 \%$ & $22 \%$ \\
\hline Private households with employed persons & $26 \%$ & $3 \%$ & $16 \%$ \\
\hline Other sector & $35 \%$ & $58 \%$ & $45 \%$ \\
\hline \multicolumn{4}{|l|}{ Occupation (col\%) } \\
\hline Occupation cat. 1 (Managers etc.) & $14 \%$ & $39 \%$ & $25 \%$ \\
\hline Occupationa cat. 2 (Skilled trades) & $11 \%$ & $22 \%$ & $16 \%$ \\
\hline Occupation cat. 3 (Elementary occ. etc.) & $75 \%$ & $39 \%$ & $59 \%$ \\
\hline Gross hourly pay $(\mathfrak{E})$, mean & 6.54 & 7.64 & 7.06 \\
\hline $\mathrm{sd}$ & $(3.45)$ & $(4.14)$ & $(3.82)$ \\
\hline$n$ & 48 & 43 & 91 \\
\hline
\end{tabular}

Notes: Percent totals do not always add up to $100 \%$ due to rounding 
Table A3: Characteristics and employment of A8 migrants registering with the Workers Registration Scheme (WRS) during May-Sep 2004, \%

\begin{tabular}{|c|c|}
\hline \multicolumn{2}{|l|}{ Nationality: } \\
\hline Poland & $56 \%$ \\
\hline Slovakia & $10 \%$ \\
\hline Czech Republic & $7 \%$ \\
\hline Lithuania & $16 \%$ \\
\hline Hungary & $3 \%$ \\
\hline Latvia & $7 \%$ \\
\hline Estonia & $2 \%$ \\
\hline Slovenia & $<1 \%$ \\
\hline Female: & $47 \%$ \\
\hline Has dependents living in the UK: & $3 \%$ \\
\hline \multicolumn{2}{|l|}{ Age: } \\
\hline $18-24$ & $45 \%$ \\
\hline $25-34$ & $39 \%$ \\
\hline $35-44$ & $9 \%$ \\
\hline $45-54$ & $5 \%$ \\
\hline $55-64$ & $1 \%$ \\
\hline $65+$ & $<1 \%$ \\
\hline \multicolumn{2}{|l|}{ Top five sectors of employment: } \\
\hline Hospitality and catering & $30 \%$ \\
\hline Administration, Business and Management (include. Recruitment agencies) & $20 \%$ \\
\hline Agriculture & $17 \%$ \\
\hline Manufacturing & $7 \%$ \\
\hline Food, Fish and Meat Processing & $5 \%$ \\
\hline \multicolumn{2}{|l|}{ Top five occupations (July-Sep): } \\
\hline Process operatives & $16 \%$ \\
\hline Kitchen and catering assistants & $7 \%$ \\
\hline Waiter/Waitress & $6 \%$ \\
\hline Packer & $5 \%$ \\
\hline Cleaner/Domestic staff & $5 \%$ \\
\hline Earning between $£ 4.50$ - $£ 5.90$ per hour: & $80 \%$ \\
\hline \multicolumn{2}{|l|}{ Location: } \\
\hline London & $24 \%$ \\
\hline Anglia & $19 \%$ \\
\hline South Central & $11 \%$ \\
\hline South East & $10 \%$ \\
\hline Midlands & $8 \%$ \\
\hline Elsewhere & $28 \%$ \\
\hline
\end{tabular}

Source: UK Home Office and DWP (2004), Accession Monitoring Report May - September 2004 
Table A4 "Immigration status" and associated rights, 2004

\begin{tabular}{|c|c|c|c|c|c|}
\hline Immigration status & $\begin{array}{l}\text { Maximum } \\
\text { duration of } \\
\text { stay }\end{array}$ & $\begin{array}{l}\text { Lead to } \\
\text { settlement? }\end{array}$ & Switch & $\begin{array}{l}\text { Labour market: rights and } \\
\text { restrictions }\end{array}$ & $\begin{array}{l}\text { Family } \\
\text { Reunion }\end{array}$ \\
\hline $\begin{array}{l}\text { Seasonal } \\
\text { Agricultural } \\
\text { Workers (SAWS) }\end{array}$ & 6 months. & No & No & $\begin{array}{l}\text { Can only work for approved } \\
\text { agricultural employers }\end{array}$ & No \\
\hline $\begin{array}{l}\text { Sector Based } \\
\text { Scheme (SBS) }\end{array}$ & 12 months. & No & No & $\begin{array}{l}\text { Can only work for named } \\
\text { employers in particular } \\
\text { sectors (hospitality, food } \\
\text { processing) }\end{array}$ & No \\
\hline $\begin{array}{l}\text { Persons intending to } \\
\text { establish themselves } \\
\text { in business ("self- } \\
\text { employed") }\end{array}$ & $\begin{array}{l}1 \text { year initially, } \\
\text { but may be } \\
\text { extended }\end{array}$ & Yes & $\begin{array}{l}\text { To certain } \\
\text { categories. }\end{array}$ & $\begin{array}{l}\text { Must have } £ 200,000 \text { to } \\
\text { invest and create } \\
\text { employment for at least } 2 \\
\text { UK residents (plus some } \\
\text { other requirements) }\end{array}$ & Yes \\
\hline ECAA & & & & $\begin{array}{l}\text { CEEC nationals**: Must } \\
\text { have business plan. Does } \\
\text { not have to have } £ 200,000\end{array}$ & \\
\hline Student & $\begin{array}{l}\text { Normally until } \\
\text { four months } \\
\text { after the end of } \\
\text { a course, or } 1 \\
\text { year initially }\end{array}$ & No & $\begin{array}{l}\text { To dependant } \\
\text { and some } \\
\text { employment } \\
\text { categories } \\
\text { only }\end{array}$ & $\begin{array}{l}\text { Usually } 20 \text { hours per week } \\
\text { in term time. More than } 20 \\
\text { hours permitted in holidays }\end{array}$ & Yes \\
\hline $\begin{array}{l}\text { Spouse/partner (not } \\
\text { fiancé(e)s }\end{array}$ & $\begin{array}{l}\text { Initially } 2 \text { years, } \\
\text { could be } \\
\text { extended } \\
\text { depending on } \\
\text { case }\end{array}$ & Yes & $\begin{array}{l}\text { Limited } \\
\text { categories }\end{array}$ & $\begin{array}{l}\text { Permitted to work once } \\
\text { entry clearance or leave to } \\
\text { remain has been granted. }\end{array}$ & N/A \\
\hline $\begin{array}{l}\text { "A8" citizen (post } \\
\text { May 2004) }\end{array}$ & $\begin{array}{l}\text { No formal time } \\
\text { limit on stay. } \\
\text { No conditions } \\
\text { of entry }\end{array}$ & Yes & N/A & $\begin{array}{l}\text { Once work is obtained must } \\
\text { "register" with Work } \\
\text { Permits UK, unless self- } \\
\text { employed or other specified } \\
\text { categories exempted from } \\
\text { registration }\end{array}$ & Yes \\
\hline
\end{tabular}

Sources: Immigration, Nationality \& Refugee Law Handbook 2002, Joint Council for the Welfare of Immigrants and www.ind.homeoffice.gov.uk (Table taken from Anderson et al. 2006)

Notes:

* In some categories it is possible to obtain limited extension (e.g. au pair can obtain a 6 month extension as a visitor.) This is not included in the stated maximum duration.

**The group of countries known as the "Central and Eastern Europe Countries" (CEEC) include Bulgaria, Czech Republic, Estonia, Hungary, Latvia, Lithuania, Poland, Romania, Slovakia and Slovenia. 
Table A5: Gross hourly pay of CS respondents, before and after EU enlargement (£)

\begin{tabular}{|c|c|c|c|c|c|c|c|c|c|c|}
\hline & \multicolumn{3}{|c|}{ BEFORE } & \multicolumn{3}{|c|}{ AFTER } & \multicolumn{3}{|c|}{ CHANGE } & \multirow{2}{*}{$\begin{array}{c}\text { DiD } \\
\text { A8-NA8 } \\
\end{array}$} \\
\hline & A8 & NA8 & Total & A8 & NA8 & Total & A8 & NA8 & Total & \\
\hline Gross hourly pay (£) & 6.76 & 8.74 & 7.57 & 7.56 & 9.12 & 8.19 & 0.80 & 0.38 & 0.62 & 0.42 \\
\hline (sd) or $\%$ & $(2.54)$ & (4.99) & $(3.85)$ & $(2.84)$ & $(5.03)$ & $(3.95)$ & $11.8 \%$ & $4.3 \%$ & $8.2 \%$ & \\
\hline $\mathrm{N}$ & 131 & 90 & 221 & 131 & 90 & 221 & & & & \\
\hline \multicolumn{11}{|l|}{ By gender: } \\
\hline male & 7.49 & 10.99 & 8.83 & 8.31 & 11.34 & 9.47 & 0.82 & 0.35 & 0.64 & 0.47 \\
\hline (sd) or $\%$ & $(2.66)$ & $(5.38)$ & $(4.27)$ & $(2.83)$ & $(5.37)$ & $(4.25)$ & $10.9 \%$ & $3.2 \%$ & $7.2 \%$ & \\
\hline $\mathrm{N}$ & 85 & 53 & 138 & 85 & 53 & 138 & & & & \\
\hline female & 5.41 & 5.51 & 5.45 & 6.19 & 5.94 & 6.08 & 0.78 & 0.43 & 0.63 & 0.35 \\
\hline$(\mathrm{sd})$ or $\%$ & (1.59) & $(1.25)$ & $(1.44)$ & $(2.33)$ & $(1.84)$ & $(2.12)$ & $14.4 \%$ & $7.8 \%$ & $11.6 \%$ & \\
\hline $\mathrm{N}$ & 46 & 37 & 83 & 46 & 37 & 83 & & & & \\
\hline \multicolumn{11}{|c|}{ By type of employment: } \\
\hline employee & 6.39 & 6.06 & 6.28 & 7.2 & 6.5 & 6.96 & 0.81 & 0.44 & 0.68 & 0.37 \\
\hline (sd) or $\%$ & $(2.34)$ & (1.77) & $(2.16)$ & $(2.68)$ & $(2.15)$ & $(2.52)$ & $12.7 \%$ & $7.3 \%$ & $10.8 \%$ & \\
\hline $\mathrm{N}$ & 105 & 56 & 161 & 105 & 56 & 161 & & & & \\
\hline self-employed & 8.24 & 13.42 & 11.3 & 9.46 & 13.72 & 11.97 & 1.22 & 0.30 & 0.67 & 0.92 \\
\hline (sd) or $\%$ & $(2.81)$ & (5.29) & (5.1) & $(2.97)$ & $(5.27)$ & $(4.92)$ & $14.8 \%$ & $2.2 \%$ & $5.9 \%$ & \\
\hline $\mathrm{N}$ & 23 & 33 & 56 & 23 & 33 & 56 & & & & \\
\hline
\end{tabular}

